\title{
Physiological and Antagonistic Properties of Pichia kluyveri for Curative and Preventive Treatments Against Post-Harvest Fruit Fungi
}

\author{
Maxwell Mewa-Ngongang ${ }^{1,2} \odot$, Heinrich Wilbur du Plessis ${ }^{1 *} \oplus^{\oplus}$, Boredi Silas Chidi ${ }^{1,2} \odot$,

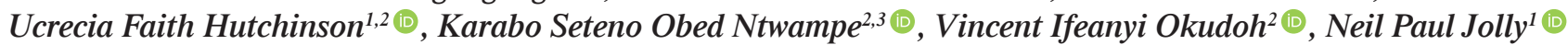 \\ ${ }^{1}$ Post-Harvest and Agro-Processing Technologies, ARC Infruitec-Nietvoorbij \\ (The Fruit, Vine and Wine Institute of the Agricultural Research Council), Private Bag X5026, Stellenbosch, 7599, South Africa \\ ${ }^{2}$ Bioresource Engineering Research Group (BioERG), Department of Biotechnology, Cape Peninsula University of Technology, \\ P.O. Box 652, Cape Town, 8000, South Africa \\ ${ }^{3}$ Center of Excellence in Carbon-Based Fuels, School of Chemical and Minerals Engineering, North-West University, \\ Private Bag X1290, Potchefstroom 2520, South Africa
}

Key words: biocontrol, Botrytis cinerea, Monilinia laxa, spoilage, antagonistic yeast

Postharvest fruit loss due to spoilage is mainly attributed to fungal infections. Synthetic chemicals can be used to preserve fruits, but they are expensive and pose risks to human health. The replacement of these chemicals by safer and cost-effective biocontrol agents is now a priority. This study investigated the physiological characteristics of Pichia kluyveri and its potential use as a biofungicide. The antagonistic effect of $P$. kluyveri against Botrytis cinerea and Monilinia laxa was tested on yeast peptone dextrose agar, grapes, apples, and pears. Yeast growth was variably possible at different temperatures, $\mathrm{pH}$, and salinity levels. Strain-dependent antagonistic responses were observed on agar plates, where M. laxa was the more sensitive fungus to the antagonistic yeast. $P$. kluyveri demonstrated strong physiological properties under stressful temperature, $\mathrm{pH}$, and salinity conditions. Preventive applications of $P$. kluyveri to apples were $95 \%$ effective against B. cinerea and $100 \%$ effective against $M$. laxa. Fruit type-dependent responses were evident on pears. Similarly, preventive application on grapes was also effective against the fungal pathogens studied. In general, the antagonistic responses were both fungus- and treatment- (curative and preventive) dependent. Therefore, the preventive use of $P$. kluyveri against post-harvest fruit-fungal infections proved to be an effective method for biological control of grapes, apples, and pears against fungal spoilage organisms Botrytis cinerea and Monilinia laxa.

\section{INTRODUCTION}

Fruits are important in a balanced diet, as they are generally rich in fibre, minerals, water, and vitamins. Unfortunately, the majority of fruits are lost or their shelf life is shortened due to spoilage by fungal pathogens [Zhu, 2006]. While pre-harvest infections and spoilage is a problem [Fourie et al., 2002], $25 \%$ of fruit spoilage occurs during post-harvest handling and is of major concern to the global agricultural industry [Droby, 2005; Singh \& Sharma, 2007]. Prior to thermal preservation techniques, Penicillium expansum was responsible for complete post-harvest spoilage of apples globally [Morales et al., 2007]. In table grapes, apples, and many other crop species, Botrytis cinerea, Colletotrichum acutatum and Rhizopus stolonifer are usually responsible for spoilage [Sharma et al., 2009; Williamson et al., 2007]. Additionally, brown rot and grey mould of South African stone fruits are linked to Monilinia laxa and B. cinerea, respectively [Fourie et al., 2002].
Fruit-derived beverages are also subject to microbial spoilage, all which impacts negatively on the economy [Parveen et al., 2016]. Dekkera, Zygosaccharomyces, Pichia, and Hanseniaspora species are the most common spoilage organisms of fruit-derived beverages [Du Toit \& Pretorius, 2000; Sáez et al., 2010].

The reduction of microbial spoilage in fruits is conventionally achieved by treatment with chemical fungicides. However, organisations, such as the World Health Organization and the European Economic Community highlighted major health-related concerns associated with their usage in food industries [Ciani \& Fatichenti, 2001]. In addition, the resistance of some pathogens to chemical preservatives often prompts an increase in chemical preservative dosages, above acceptable limits [Benito et al., 2009], which can negatively affect product quality. As a result, safer, cheaper, and cost-effective alternatives have recently been the central focus. The use of safer biological systems such as yeast is another potential

\footnotetext{
* Corresponding Author:

Tel.: + 27218093063 ;

Email: DPlessisHe@arc.agric.za
} 
source of biocontrol agents against fruit and fruit-derived beverages [Ciani \& Fatichenti, 2001; Comitini et al., 2004a; Grzegorczyk et al., 2017; Mehlomakulu et al., 2014; Parveen et al., 2016]. Thus far, several yeasts have been reported to have antagonistic properties against fruit and fruit-derived beverages spoilage pathogens [Aloui et al., 2015; Cordero-Bueso et al., 2017; El Ghaouth et al., 2004; Mehlomakulu et al., 2014; Mewa-Ngongang et al., 2017, 2019a]. Yeasts are excellent biocontrol agents because their growth requirements are simple and their growth kinetics on many fruits and in beverages are competitive [Liu et al., 2013; Muccilli \& Restuccia, 2015]. An additional advantage of biological systems is their ability to produce extracellular compounds with antimicrobial properties against many fruit pathogens such as spoilage yeasts, bacteria, and fungi [Comitini et al., 2004a,b; Grzegorczyk et al., 2017; Mehlomakulu et al., 2014].

Several authors have highlighted the importance of non-Saccharomyces yeasts in addressing food spoilage [Mewa-Ngongang et al., 2017, 2019b; Oro et al., 2014]. Their widespread use in the food industry, their ability to handle and grow quicker than spoilage organisms, and their ability to produce killer toxins have been widely acknowledged. The biotechnological potential of Pichia kluyveri has been highlighted as a producer of aromatic and growth inhibition compounds in beverages [Crafack et al., 2013; Jolly et al., 2014]. The aim of this study was to evaluate the physiological properties of $P$. kluyveri and to assess its potential in suppressing post-harvest fungal growth of $B$. cinerea and $M$. laxa on yeast peptone dextrose agar, apples (Golden delicious), table grapes (Regal seedless), and pears (Packham's Triumph).

\section{MATERIALS AND METHODS}

\section{Strain selection and maintenance}

Previously isolated from Marula (Scelerocarya birrea) juice, the yeast $P$. kluyveri Y1164 was selected after screening several yeasts from the ARC Infruitec-Nietvoorbij yeast culture collection (The Fruit, Vine and Wine Institute of the Agricultural Research Council, Stellenbosch, South Africa). B. cinerea and M. laxa were supplied by the Post-harvest Pathology Laboratory (ARC Infruitec-Nietvoorbij). Yeast cells and spores of $B$. cinerea and $M$. laxa were propagated at $25^{\circ} \mathrm{C}$ and maintained at $4^{\circ} \mathrm{C}$ on yeast peptone dextrose agar (yeast extract $10 \mathrm{~g} / \mathrm{L}$, peptone $20 \mathrm{~g} / \mathrm{L}$, dextrose $20 \mathrm{~g} / \mathrm{L}$, and $20 \mathrm{~g} / \mathrm{L}$ agar) (YPDA, Biolab, Merck, Modderfontein, South Africa). The $\mathrm{pH}$ was 6.5 after autoclaving.

\section{Yeast cells and fungal spore preparation}

To investigate the antagonistic effects of $P$. kluyveri on fungal growth, yeast cells were cultivated in YPD broth (Biolab, Merck) at a $\mathrm{pH}$ of 6.5 for $24 \mathrm{~h}$ at $25^{\circ} \mathrm{C}$, using a rotary shaker (150 rpm). Fungus spores were detached from the YPDA cultures and suspended in sterile distilled water. A microscope (SN-EU 1712504, BioBlue Lab, Euromex Microscopes, Arnhem, Holland) and a Neubauer counting chamber were used to determine the cell or spore concentrations at $400 \times$ magnification.

\section{Characterisation of physiological properties: Salinity, pH, and temperature}

The ability of $P$. kluyveri to grow under different salinity $(0.05,0.10,0.15$, and $0.20 \mathrm{~g} / \mathrm{mL} \mathrm{NaCl}), \mathrm{pH}(1,2,3,7$, and 8), and temperature $\left(5,15,30\right.$, and $\left.40^{\circ} \mathrm{C}\right)$ conditions was investigated. A pre-inoculum was prepared by transferring a wire loopful of $P$. kluyveri cells into a test tube containing $10 \mathrm{~mL}$ of sterile YPD broth and incubated without agitation at $28^{\circ} \mathrm{C}$ for $24 \mathrm{~h}$. Subsequently, test tubes containing $5 \mathrm{~mL}$ of $\mathrm{pH}$ - and saline-adjusted YPD broth (in triplicate) were inoculated at a final concentration of $10^{3}$ cells/mL of $P$. kluyveri and incubated without agitation at $28^{\circ} \mathrm{C}$ for 7 days. For the determination of growth at various temperatures, test tubes containing $5 \mathrm{~mL}$ of YPD broth were inoculated as mentioned above, but incubated at different temperatures for 7 days. After incubation, cell concentrations were determined microscopically using a Neubauer counting chamber. Based on the initial inoculum of $10^{3}$ cells $/ \mathrm{mL}$, low, medium, and high growth was defined as those concentrations ranging from $10^{3}$ to $10^{4}, 10^{4}$ to $10^{5}$, and $10^{5}$ to $10^{6}$ cells $/ \mathrm{mL}$, respectively.

\section{Antagonistic effect of $\boldsymbol{P}$. kluyveri on fungal growth: Plate assay}

This assay was adapted from Medina-Córdova et al. [2016]. YPDA plates were prepared and a mycelial culture disc $(5 \mathrm{~mm})$ of either $B$. cinerea or $M$. laxa was placed $2.5 \mathrm{~cm}$ away from the plate edges. A volume of $15 \mu \mathrm{L}$ yeast cells suspension $\left(10^{8}\right.$ cells $\left./ \mathrm{mL}\right)$ was deposited $3 \mathrm{~cm}$ from the disc and the plates were sealed with laboratory film (Parafilm ${ }^{\circledR}$ ). After incubation at $28^{\circ} \mathrm{C}$ for 7 days, the diameter of the fungal growth zones was measured. Negative controls were prepared by seeding a mycelial disc at the centre of the YPDA plate under analogous incubation conditions. The antagonistic effect of the yeast was measured in terms of the comparative reduction in fungal growth (diameter) between treatments and negative controls (average of three replicates).

\section{Preventive and curative treatments: Apple, grape, and pear bioassays}

Golden Delicious apples (Malus domestica) and Packham's Triumph pears (Pyrus communis 'Bosc') were obtained from a local producer, Two-A-Day Group Ltd (Grabouw, South Africa). Regal Seedless table grapes (Vitis vinifera) were obtained from the Cultivar Development Division of ARC Infruitec-Nietvoorbij. Apples and pears (10 replicates consisting of three pears/apples per replicate) were washed, dried, and sprayed with $70 \%$ ethanol and uniformly wounded with a sterile cork borer (approximately $5 \mathrm{~mm}$ diameter and $3 \mathrm{~mm}$ deep). The ethanol was allowed to dry prior to the next step. After wound infliction, fruits were allowed to dry before undergoing preventive or curative treatments. For preventive treatments, wounded fruits were inoculated with $20 \mu \mathrm{L}$ $\left(10^{6}\right.$ cells $\left./ \mathrm{mL}\right)$ of $P$. kluyveri cell suspension using a micropipette and incubated overnight at room temperature. Subsequently, the yeast cells were allowed to colonise the fruits for $24 \mathrm{~h}$ before inoculation with $20 \mu \mathrm{L}\left(10^{5}\right.$ cells $\left./ \mathrm{mL}\right)$ of $B$. cinerea or M. laxa suspension. For curative treatments, the wounded fruits were inoculated with $20 \mu \mathrm{L}$ ( $10^{5}$ fungal spores $\left./ \mathrm{mL}\right)$ of $B$. cinerea or M. laxa, incubated for $24 \mathrm{~h}$ and then inoculated 
with $20 \mu \mathrm{L}\left(10^{6}\right.$ cells $\left./ \mathrm{mL}\right)$ of $P$. kluyveri suspension. Treated fruit was maintained at $-0.5^{\circ} \mathrm{C}$ for 4 weeks, and then stored at room temperature $\left( \pm 20^{\circ} \mathrm{C}\right)$ for 7 days, to simulate shipping conditions and shelf life in a commercial setting. Positive results were characterised by the absence of fungal development on the fruit surfaces. For preventive and curative treatments/bioassays, negative controls were prepared by inoculating fruits with $20 \mu \mathrm{L}$ ( $10^{5}$ fungal spores $/ \mathrm{mL}$ ) of $B$. cinerea or $M$. laxa suspensions under similar maintenance and storage conditions. During the incubation period for all the treatments, there was an $80 \%$ relative humidity. Comparative analysis of the differences in lesion diameters/growth inhibition between the negative controls and inoculated fruits was done to determine if the yeast is a successful biocontrol agent against $B$. cinerea and M. laxa. For both treatments, the percentage inhibition was obtained, considering that the negative control was $100 \%$ of the lesion diameter. Table grapes (20 replicates consisting of 10 grape berries per replicate) were uniformly wounded with a sterile needle ( $2 \mathrm{~mm}$ diameter, 1 wound per berry) and allowed to dry prior to preventive and curative treatments. For preventive treatments, wounded grapes (10 grapes per replicate) were sprayed with $10 \mathrm{~mL}\left(10^{6}\right.$ cells $\left./ \mathrm{mL}\right)$ of $P$. kluyveri cell suspension, incubated overnight at room temperature and sprayed with $10 \mathrm{~mL}\left(10^{5}\right.$ cells $\left./ \mathrm{mL}\right)$ of $B$. cinerea or M. laxa suspension. For curative treatments, the wounded grapes were sprayed with $10 \mathrm{~mL}\left(10^{5}\right.$ fungal spores $\left./ \mathrm{mL}\right)$ of $B$. cinerea or $M$. laxa, incubated for $24 \mathrm{~h}$, and then sprayed with $10 \mathrm{~mL}\left(10^{6}\right.$ cells $\left./ \mathrm{mL}\right)$ of $P$. kluyveri suspension. The negative controls (10 berries each) were prepared by spraying the fungal spores on the wounded berries without yeast treatment. All grape treatments were also maintained at $-0.5^{\circ} \mathrm{C}$ for 4 weeks, and then stored at room temperature $\left( \pm 20^{\circ} \mathrm{C}\right)$ for 7 days. The antagonistic properties of $P$. kluyveri were analysed visually by assessing the grape colour changes and fungal development on treated grapes.

\section{Statistical analysis}

The experiment was randomised and the data for each experiment was analysed separately. To determine whether there were significant differences within the physiological parameters ( $\mathrm{pH}$, temperature, and salinity), analysis of variance was performed using general linear means procedure of SAS version 9.4 (SAS Institute Inc, Cary, NC, USA). Fisher's least significant difference (LSD) values were calculated at the $5 \%$ probability level $(\mathrm{p}=0.05)$ to facilitate comparison between treatment means.

\section{RESULTS AND DISCUSSION}

\section{Physiological properties of $\boldsymbol{P}$. kluyveri}

The results in Table 1 show growth characteristics of $P$. kluyveri under different $\mathrm{pH}$, saline, and temperature conditions in YPD. One of the required properties of biocontrol agents (e.g., yeast) is the ability to tolerate a broad spectrum of the aforementioned conditions. These conditions are fruit type-dependent and critical during postharvest because they affect the growth of both antagonistic yeasts and fruit fungal pathogens. Prior to postharvest control treatments, it was important to establish whether yeast growth was possible under a very wide spectrum of conditions. Relatively low yeast count was observed at $5^{\circ} \mathrm{C}\left(1.55 \times 10^{3}\right.$ cells $\left./ \mathrm{mL}\right)$ and $40^{\circ} \mathrm{C}\left(1.58 \times 10^{3}\right.$ cells $\left./ \mathrm{mL}\right)$, at $\mathrm{pH} 1\left(1.64 \times 10^{3}\right.$ cells $\left./ \mathrm{mL}\right)$, and $0.15 \mathrm{~g} / \mathrm{mL}\left(1.37 \times 10^{3}\right.$ cells $\left./ \mathrm{mL}\right)$ and $0.20 \mathrm{~g} / \mathrm{mL}$ $\left(1.07 \times 10^{3}\right.$ cells $\left./ \mathrm{mL}\right)$ salinity. A moderate count was observed at $0.10 \mathrm{~g} / \mathrm{mL}$ salinity $\left(1.41 \times 10^{4}\right.$ cells $\left./ \mathrm{mL}\right)$. The highest cell counts were obtained at $15^{\circ} \mathrm{C}\left(3.75 \times 10^{5}\right.$ cells $\left./ \mathrm{mL}\right)$ and $30^{\circ} \mathrm{C}\left(3.17 \times 10^{5}\right.$ cells $\left./ \mathrm{mL}\right)$, at $\mathrm{pH} 2\left(1.86 \times 10^{5}\right.$ cells $\left./ \mathrm{mL}\right)$, pH $3\left(1.74 \times 10^{5}\right.$ cells $\left./ \mathrm{mL}\right)$, pH $7 \quad\left(5.50 \times 10^{5}\right.$ cells $\left./ \mathrm{mL}\right)$, pH $8 \quad\left(4.55 \times 10^{5} \quad\right.$ cells $\left./ \mathrm{mL}\right)$, and $0.05 \mathrm{~g} / \mathrm{mL}$ salinity $\left(4.72 \times 10^{5}\right.$ cells $\left./ \mathrm{mL}\right)$. The optimal growth temperature range of $P$. kluyveri corresponds to the South African mean annual temperatures between $17-22^{\circ} \mathrm{C}$ ["CapeFarmMapper," n.d.]. Meaning that yeast growth and antagonistic properties can be stimulated under most agricultural and postharvest conditions of South Africa.

The ideal $\mathrm{pH}$ and saline conditions for P. kluyveri also relate to the intrinsic properties of most fruits, i.e. $\mathrm{pH} 3.2-$ -4.5 and $<0.1 \mathrm{~g} / \mathrm{mL}$ salt, respectively [Kessels, 2003]. These findings were also comparable to the findings of Psani \& Kotzekidou [2006] where the large majority of Debaryomyces hansenii (15 strains) and Torulaspora delbrueckii (32 strains) were able to grow optimally at $15^{\circ} \mathrm{C}, \mathrm{pH} 2.5$, and $0.1 \mathrm{~g} / \mathrm{mL}$ $\mathrm{NaCl}$. Previously, both yeast growth and the killer properties of yeast were associated with changes in environmental conditions such as temperature, salinity, and $\mathrm{pH}$ [Tipper \& Bostian, 1984]. As in the current study, Çelik et al. [2017] also reported insignificant growth rates of most yeast strains (P. kluyveri, Candida zemplinina, P. occidentalis, and Saccharomyces cerevisiae) when the temperature was below $15^{\circ} \mathrm{C}$ under grape-must fermentation conditions ( $\mathrm{pH} 3.18$ ). Although this study is the first to report on some antagonistic

TABLE 1. Cell count of Pichia kluyveri Y1164 grown for 7 days at different temperatures, $\mathrm{pH}$, and salinity levels.

\begin{tabular}{l|c|c}
\hline Parameter & Value & Cell count $($ cells $/ \mathrm{mL})$ \\
\hline & 5 & $1.55 \times 10^{3} \pm 2.59 \times 10^{2, \mathrm{c}}$ \\
Temperature $\left({ }^{\circ} \mathrm{C}\right)$ & 15 & $3.75 \times 10^{5} \pm 2.69 \times 10^{4, \mathrm{a}}$ \\
& 30 & $3.17 \times 10^{5} \pm 1.44 \times 10^{4, \mathrm{~b}}$ \\
& 40 & $1.58 \times 10^{3} \pm 3.77 \times 10^{2, \mathrm{c}}$ \\
\hline & 1 & $1.64 \times 10^{3} \pm 1.56 \times 10^{2, \mathrm{~d}}$ \\
& 2 & $1.86 \times 10^{5} \pm 0.91 \times 10^{4, \mathrm{c}}$ \\
$\mathrm{pH}$ & 3 & $1.74 \times 10^{5} \pm 0.83 \times 10^{4, \mathrm{c}}$ \\
& 7 & $5.50 \times 10^{5} \pm 3.67 \times 10^{4, \mathrm{a}}$ \\
& 8 & $4.55 \times 10^{5} \pm 0.97 \times 10^{4, \mathrm{~b}}$ \\
\hline & 0.05 & $4.72 \times 10^{5} \pm 1.90 \times 10^{4, \mathrm{a}}$ \\
Salinity & 0.10 & $1.41 \times 10^{4} \pm 3.13 \times 10^{3, \mathrm{~b}}$ \\
$($ NaCl concentration, g/mL) & 0.15 & $1.37 \times 10^{3} \pm 1.44 \times 10^{2, \mathrm{~b}}$ \\
& 0.20 & $1.07 \times 10^{3} \pm 3.17 \times 10^{3, \mathrm{~b}}$ \\
\hline
\end{tabular}

The values and standard deviation in the table are means of three repeats. Different letters in a column represent statistically significant differences $(\mathrm{p}<0.05)$ for temperature, $\mathrm{pH}$ or salinity, respectively. 
properties of $P$. kluyveri, our findings on the physiological properties of $P$. kluyveri were not surprising, since another Pichia species (P. anomala J121) was previously considered efficient biocontrol yeasts because of their ability to grow under harsh conditions, i.e. temperature $\left(3-37^{\circ} \mathrm{C}\right), \mathrm{pH}(2.0$ $-12.4)$, and water activity of $0.92(\mathrm{NaCl})$ and 0.85 (glycerol) [Fredlund et al., 2004].

\section{Antagonistic effect of $\boldsymbol{P}$. kluyveri against fungal growth}

Figure 1 and Figure 2 show the antagonistic effect of $P$. kluyveri against two fruit fungal pathogens, $B$. cinerea and $M$. laxa. The mean growth diameter on the negative control was 45.58 and $63.42 \mathrm{~mm}$ for $M$. laxa and B. cinerea, respectively (Figure 1). The most sensitive fungus to the antagonistic yeast was $M$. laxa, which showed a growth inhibition of $54.6 \%$ after 7 days of incubation (Figure 2). Compared

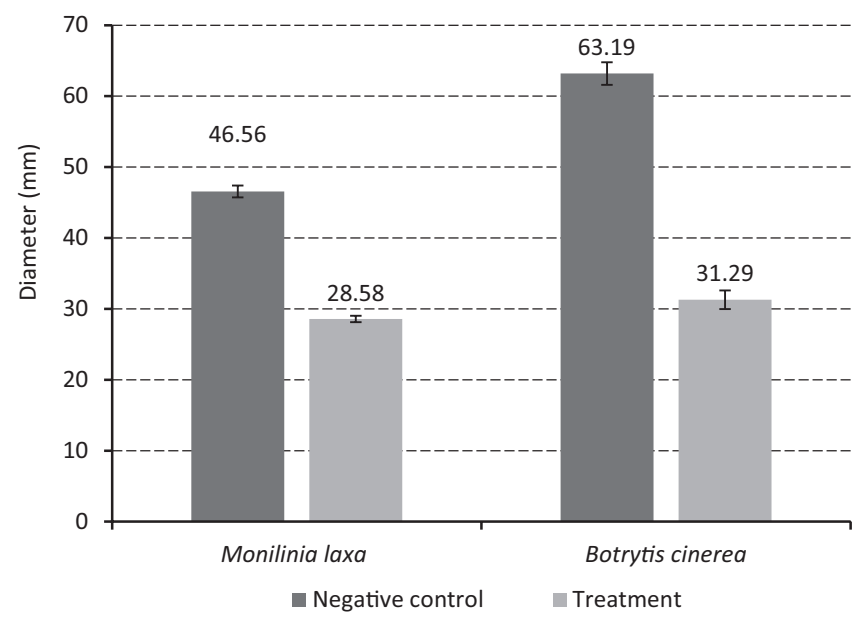

FIGURE 1. Diameters of Botrytis cinerea and Monilinia laxa growth zones (negative control) and growth of these fungi in the presence of $P i$ chia kluyveri Y1164 (treatment) on yeast peptone dextrose agar plates.
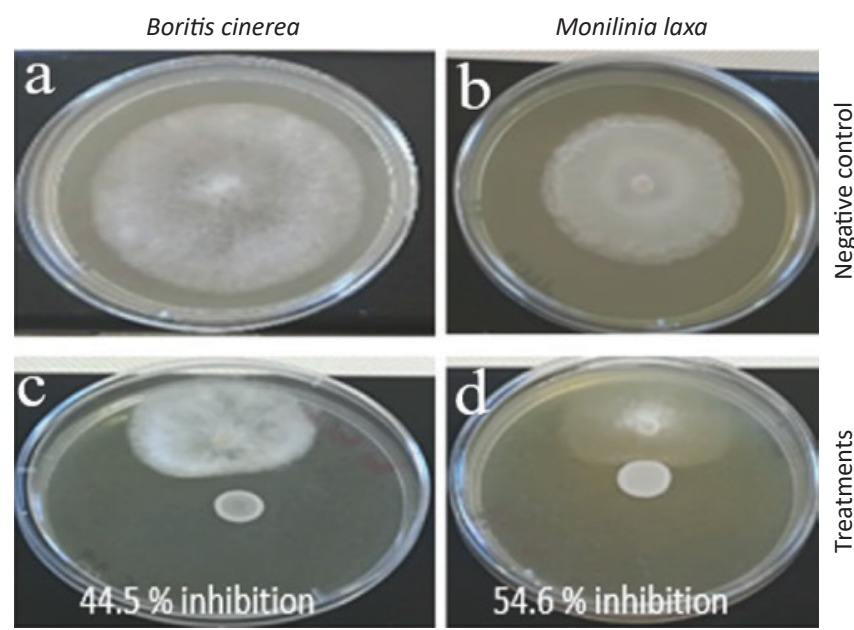

FIGURE 2. Photograph of the inhibition assay on yeast peptone dextrose agar plates showing the inhibition potential of Pichia kluyver Y1164 on Botrytis cinerea and Monilinia laxa. Growth inhibition is given as the percentage difference between fungal growth diameter of Botrytis cinerea (a) and Monilinia laxa (b) controls as well as Botrytis cinerea (c) and Monilinia laxa (d) treatments. Each plate is a representative example of three replicates. to the negative control $(\mathrm{p}<0.05), 44.5 \%$ growth inhibition was observed against $B$. cinerea. Although $B$. cinerea (negative control) grew faster than $M$. laxa on YPDA, the antagonistic effect of $P$. kluyveri was still maintained and seemed independent of fungal growth kinetics. Additionally, species-dependent antagonistic responses were evident on solidified medium assays. Previously, the screening and the identification of antimicrobial producing yeasts such as Candida intermedia [Huang et al., 2011] and Sporidiobolus pararoseus [Huang et al., 2012] was achieved on solid medium. A similar study by Mewa-Ngongang et al. [2019b] also demonstrated the broad antagonistic effect of $P$. kluyveri on solidified plate assays, therefore supporting the findings of this research. Although the pre-screening of biocontrol agents on agar media is common, more rapid and cost-effective methods still need to be developed.

\section{Preventive and curative treatments: Apple bioassay}

As shown in Figure 3 and Figure 4, P. kluyveri applied preventively, was effective in suppressing fungal growth to $95.12 \%$ (Lesion diameter, $\mathrm{LD}=3.29 \mathrm{~mm}$ ) and $100 \%(\mathrm{LD}=0.0 \mathrm{~mm})$ for $B$. cinerea and $M$. laxa, respectively. The curative treatments were not as effective, since growth suppression of B. cinerea was only $51.32 \%(\mathrm{LD}=32.77 \mathrm{~mm})$ and $45.68 \%$ $(\mathrm{LD}=26.49 \mathrm{~mm}$ ) for $M$. laxa, compared to the negative controls. As shown in Figure 3 and Figure 4 preventive/curative biocontrol treatments against both fungal pathogens (B. cinerea and M. laxa) followed similar trends where smaller lesions were observed for M. laxa. Gril et al. [2008] also categorised M. laxa as a pathogen of apple fruits, but not its principal or preferred host. Sansone et al. [2018] proved that the biocontrol of $B$. cinerea BNM 0527 was more effective under preventive rather than curative treatments on apples. These authors also showed a $75 \%$ and $48 \%$ spoilage reduction by Rhodosporidium fluviale as preventive and curative treatments, respectively. These results confirm the old notion that says, 'prevention is better than cure'.

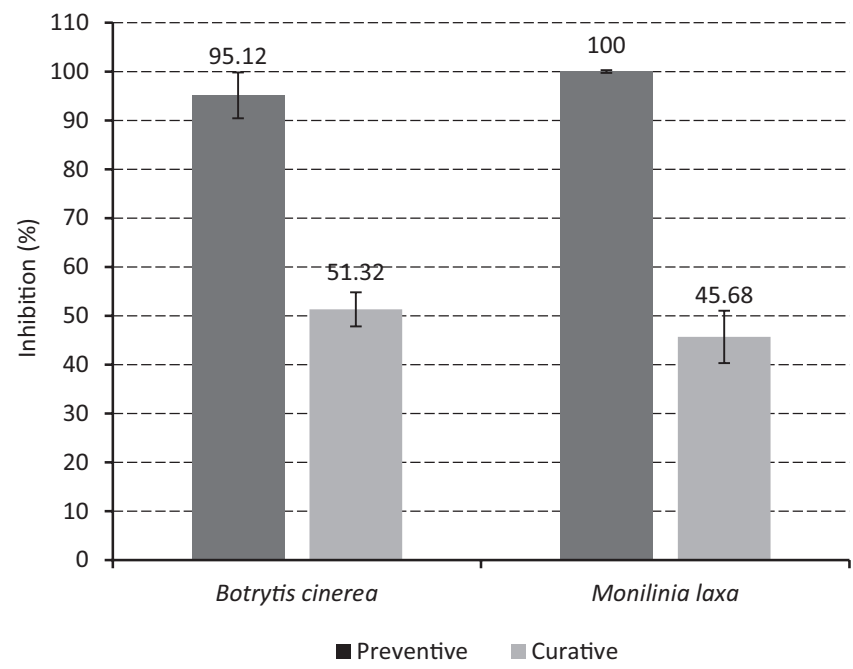

FIGURE 3. Growth inhibition of Botrytis cinerea and Monilinia laxa on apples with the associated level of biological control by Pichia kluyveri Y1164 used as preventive and curative treatments. Values are the average of 10 replicates consisting of three apples per replicate \pm standard deviation $(n=30)$. The lesion diameters, from which the percentage inhibition was obtained, are shown in Figure 4. 


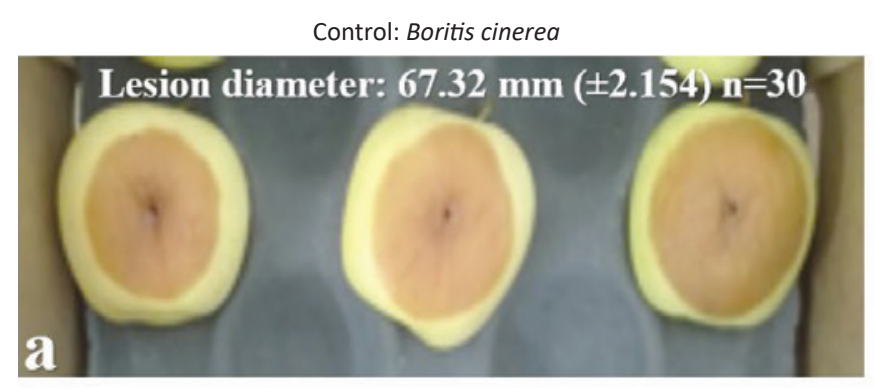

Preventive: Boritis cinerea

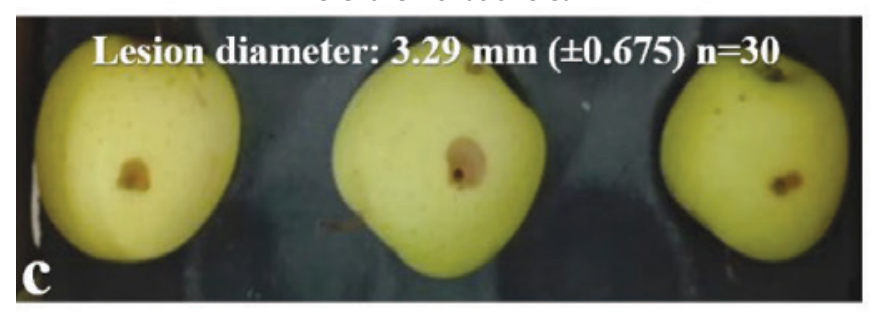

Curative: Boritis cinerea

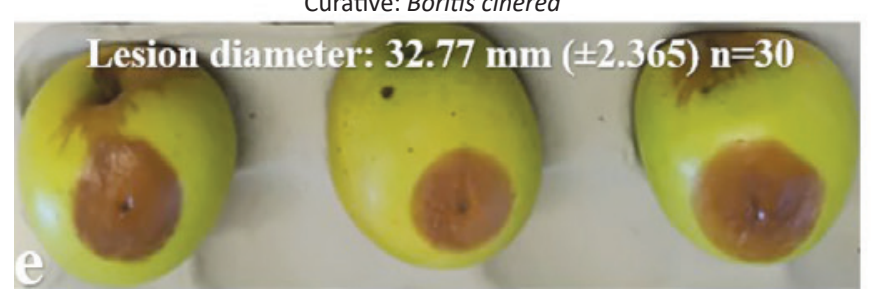

Control: Monilinia laxa

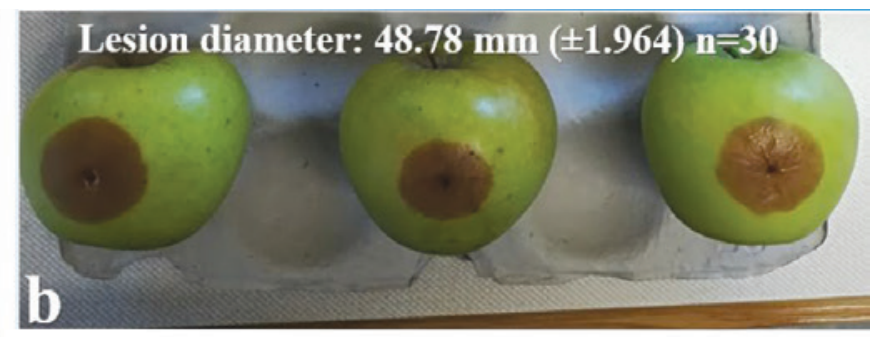

Preventive: Monilinia laxa

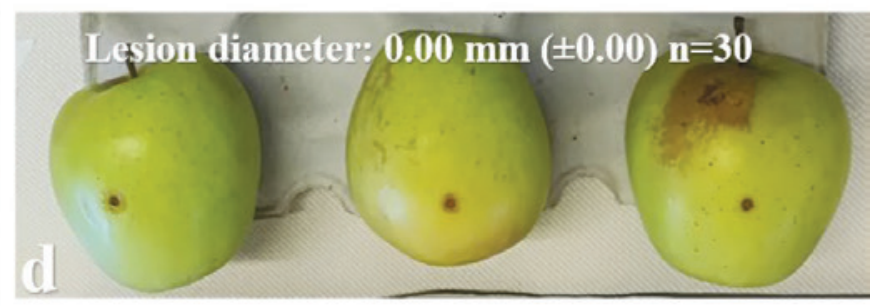

Curative: Monilinia laxa

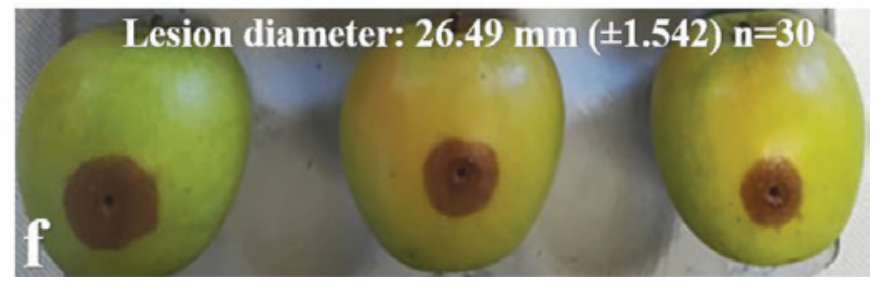

FIGURE 4. Photograph of apples showing lesion diameters because of spoilage caused by Botrytis cinerea (a) and Monilinia laxa (b) with the associated level of biological control by Pichia kluyveri Y1164 against preventive Botrytis cinerea (c) and Monilinia laxa (d) treatments as well as curative Botrytis cinerea (e) and Monilinia laxa (f) treatments. Values are the average of 10 replicates consisting of three apples per replicate \pm standard deviation $(n=30)$. Each set (consisting of three apples) is a representative example after 4 weeks at $-0.5^{\circ} \mathrm{C}$ and then at room temperature $\left( \pm 20^{\circ} \mathrm{C}\right)$ for 7 days.

\section{Preventive and curative treatments: Table grape bioassay}

The antagonistic effect of $P$. kluyveri applied as preventive and curative grape treatments on the growth of $B$. cinerea and M. laxa are shown in Figure 5. A 100\% growth inhibition was observed, which was demonstrated by the absence of spoilage for the preventive treatments. Translating to effective control of both $B$. cinerea and $M$. laxa infections, compared to the controls. Slightly different observation was made on the curative treatments where it would be important to mention that the result interpretation in this part was also based on visual observations whereby, a jar was considered as a mini bunch of grape berries that was inspected for decay not as single fruit like in the case of apples and pears. One out of 20 jars infected with $B$. cinerea in the curative treatment showed signs of spoiled berries (95\% inhibition), while a $100 \%$ inhibition was observed for the curative treatments of $M$. laxa. This result is comparable to the 100\% suppression of Aspergillus carbonarius, Colletotrichum acutatum, and Rhizopus stolonifer growth on grapes by Candida zemplinina, Candida pyralidae, Saccharomyces cerevisiae, and P. kluyveri [Fiori et al., 2014; Mewa-Ngongang et al., 2019b; Zhu et al., 2015]. Although preventive results were notable, curative biocontrol applications resulted in substandard grape colour and texture, although spoilage was vastly minimised. It is also plausible that, apart from antagonistic properties of $P$. kluyveri, volatile compounds [Fiori et al., 2014; Lutz et al., 2013], hydrolytic enzymes [Hernández et al., 2008], mycotoxins [Thompson et al., 2013] or proteases [Buzzini \& Martini, 2002] may have affected fungal growth. The results from this study also showed the effectiveness of $P$. kluyveri against $B$. cinerea and $M$. laxa growth and the advantage of preventive treatments during fruit processing.

\section{Preventive and curative treatments: Pear bioassay}

The bioassay with pear fruits confirmed the antagonistic effect of $P$. kluyveri on B. cinerea and M. laxa, with a significant $(\mathrm{p}<0.05)$ reduction in lesion diameter when applied as preventive treatments (Figure 6 and Figure 7). As a preventive treatment, $P$. kluyveri exhibited a $73.16 \%(\mathrm{LD}=9.21 \mathrm{~mm})$ and $78.65 \%(\mathrm{LD}=7.07 \mathrm{~mm})$ inhibition against $B$. cinerea and M. laxa, respectively. Curative treatments showed a $58.59 \%(\mathrm{LD}=14.21 \mathrm{~mm})$ and $52.08 \%(\mathrm{LD}=15.45 \mathrm{~mm})$ inhibition against $B$. cinerea and $M$. laxa, respectively. Enhanced control for preventive treatments could be due to the ability of the yeasts to quickly colonise the wound, release antimicrobial substances, and successfully outgrow fungal pathogens. Therefore, the use of $P$. kluyveri as a preventive treatment can provide an effective strategy to reduce post-harvest decay of pears. Results suggest that the yeast competes with the fungal pathogens for space and nutrients. However, it is also possible that $P$. kluyveri produced secondary metabolites (e.g. diffusible compounds) with antifungal properties [Andrade et al., 2014; Nally et al., 2015; Núñez et al., 2015]. 

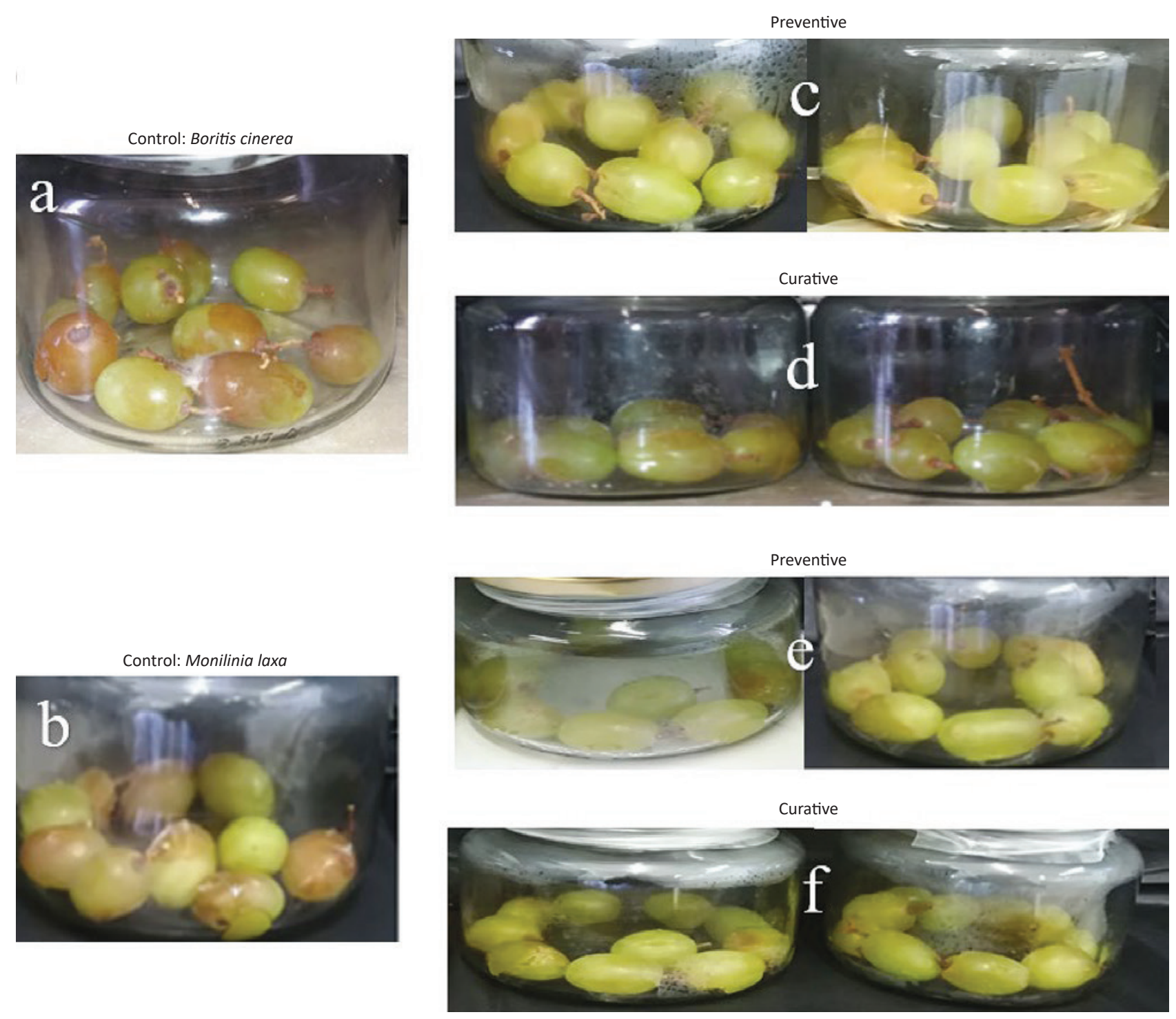

FIGURE 5. Photograph of the jars showing table grapes spoilage caused by Botrytis cinerea and Monilinia laxa and the associated biological control of Pichia kluyveri Y1164 against Botrytis cinerea (c) and Monilinia laxa (e) preventive treatments as well as Botrytis cinerea (d) and Monilinia laxa (f) curative treatments. Twenty replicates consisting of 10 grape berries per replicate were tested against both Botrytis cinerea (a) and Monilinia laxa (b) controls. Each set displayed in this figure is a representative example after 4 weeks at $-0.5^{\circ} \mathrm{C}$ and then at room temperature $\left( \pm 20^{\circ} \mathrm{C}\right)$ for 7 days.

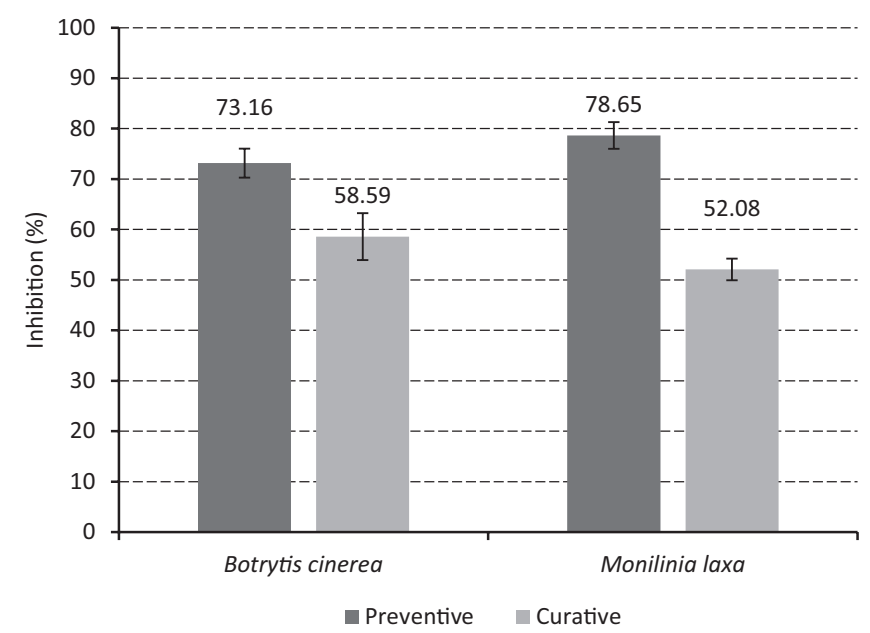

FIGURE 6. Growth inhibition of Botrytis cinerea and Monilinia laxa on pears with the associated level of biological control by Pichia kluyveri Y1164 used as preventive and curative treatments. Values are the average of 10 replicates consisting of three pears per replicate \pm standard deviation $(n=30)$. The lesion diameters, from which the percentage inhibition was obtained, are shown in Figure 7. 
Negative control: Boritis cinerea

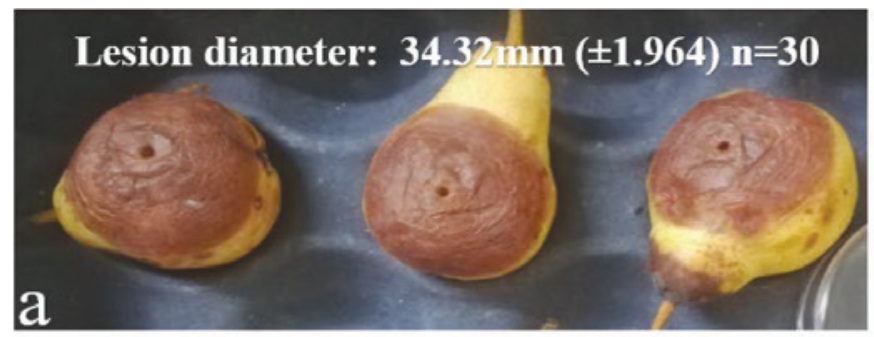

Preventive: Boritis cinerea

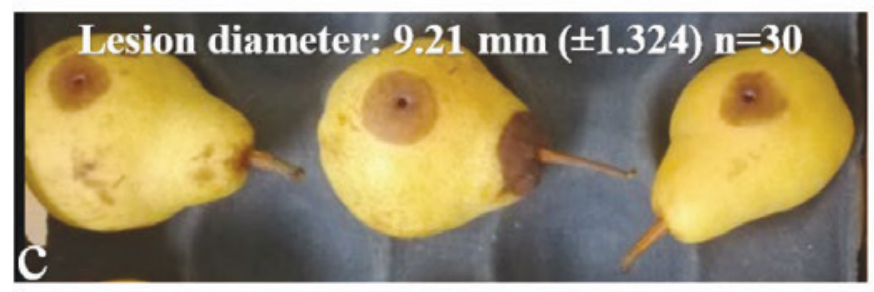

Curative: Boritis cinerea

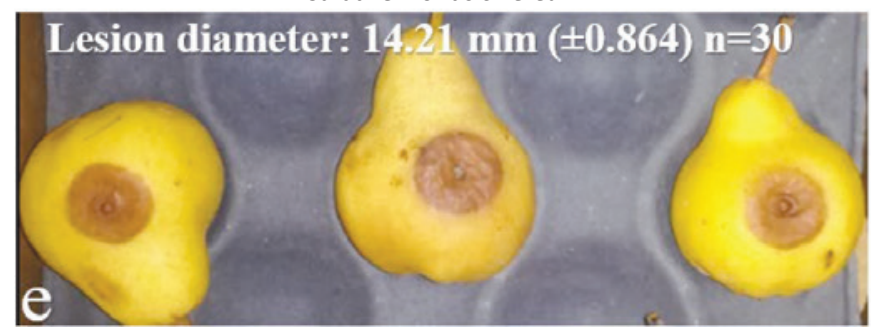

Negative control: Monilinia laxa

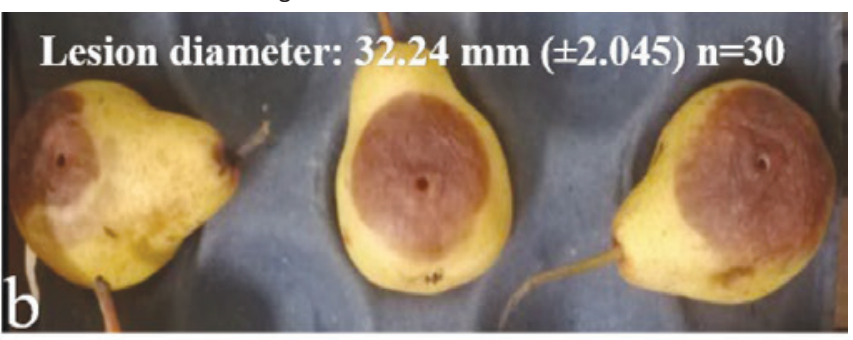

Preventive: Monilinia laxa

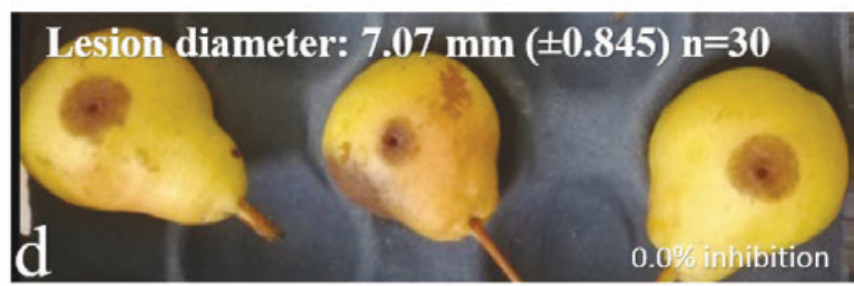

Curative: Monilinia laxa

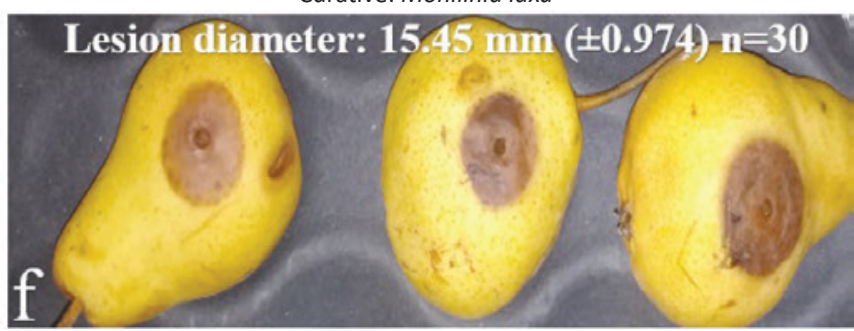

FIGURE 7. Photograph of pears showing lesion diameters because of spoilage caused by Botrytis cinerea (a) and Monilinia laxa (b) with the associated level of biological control by Pichia kluyveri Y1164 against preventive Botrytis cinerea (c) and Monilinia laxa (d) treatments as well as curative Botrytis cinerea (e) and Monilinia laxa (f) treatments. Values are the average of 10 replicates consisting of three pears per replicate \pm standard deviation ( $=30$ ). Each set (consisting of three pears) is a representative example after 4 weeks at $-0.5^{\circ} \mathrm{C}$ and then at room temperature $\left( \pm 20^{\circ} \mathrm{C}\right)$ for 7 days.

\section{CONCLUSIONS}

The biocontrol yeast $P$. kluyveri Y1164 inhibited B. cinerea and $M$. laxa growth on apples, pears, and table grapes when applied preventively. However, P. kluyveri Y1164 was not as effective when applied as a curative treatment. Biological control can be considered as a preventive strategy to reduce postharvest fungal spoilage of fruits. Exploring pre-harvest efficacy of the biocontrol yeast $P$. kluyveri Y1164, as well as its efficacy against other fruit fungal pathogens can be investigated in future studies.

\section{RESEARCH FUNDING}

Thisworkwassupported bytheAgriculturalResearchCouncil (ARC) and National Research Foundation (NRF) of South Africa (Grant Numbers: SFP160505164079 and 117833). The opinions, findings and conclusions or recommendations expressed in this publication is that of the authors alone, and the NRF accepts no liability whatsoever in this regard. The authors thank the students, interns, technicians and research assistants who contributed.

\section{CONFLICT OF INTERESTS}

Authors declare no conflict of interests.

\section{ORCID IDs}

B.S. Chidi https://orcid.org/0000-0001-8497-7596

H.W. du Plessis https://orcid.org/0000-0001-8092-6492

U.F. Hutchinson https://orcid.org/0000-0002-5219-6223

N.P. Jolly https://orcid.org/0000-0001-7278-6442

M. Mewa-Ngongang https://orcid.org/0000-0003-2588-3973 S.K.O. Ntwampe https://orcid.org/0000-0001-7516-6249

V.I. Okudoh https://orcid.org/0000-0002-8468-1338

\section{REFERENCES}

1. Aloui, H., Licciardello, F., Khwaldia, K., Hamdi, M., Restuccia, C. (2015). Physical properties and antifungal activity of bioactive films containing Wickerhamomyces anomalus killer yeast and their application for preservation of oranges and control of post-harvest green mold caused by Penicillium digitatum. International Journal of Food Microbiology, 200, 22-30.

https://doi.org/10.1016/j.ijfoodmicro.2015.01.015

2. Andrade, M.J., Thorsen, L., Rodríguez, A., Córdoba, J.J., Jespersen, L. (2014). Inhibition of ochratoxigenic moulds by Debaryomyces hansenii strains for biopreservation of dry-cured meat products. International Journal of Food Microbiology, 170, 70-77.

https://doi.org/10.1016/j.ijfoodmicro.2013.11.004

3. Benito, S., Palomero, F., Morata, A., Uthurry, C., Suárez-Lepe, J.A. (2009). Minimization of ethylphenol precursors in red wines 
via the formation of pyranoanthocyanins by selected yeasts. International Journal of Food Microbiology, 132(2-3), 145-152.

https://doi.org/10.1016/j.ijfoodmicro.2009.04.015

4. Buzzini, P., Martini, A. (2002). Extracellular enzymatic activity profiles in yeast and yeast-like strains isolated from tropical environments. Journal of Applied Microbiology, 93(2), 1020-1025. https://doi.org/10.1046/j.1365-2672.2002.01783.x

5. Cape Farm Mapper. [http://gis.elsenburg.com/apps/cfm] (accessed: 6 June 2018).

6. Çelik, Z.D., Erten, H, Darici, M., Cabaroğlu, T. (2017). Molecular characterization and technological properties of wine yeasts isolated during spontaneous fermentation of Vitis vinifera L. cv. Narince grape must grown in ancient wine making area Tokat, Anatolia. BIO Web of Conference, 9, art. no. 02017. https://doi.org/10.1051/bioconf/20170902017

7. Ciani, M., Fatichenti, F. (2001). Killer toxin of Kluyveromyces phaffii DBVPG 6076 as a biopreservative agent to control apiculate wine yeasts. Applied Environmental Microbiology, 67(7), 3058-3063.

https://doi.org/10.1128/AEM.67.7.3058-3063.2001

8. Comitini, F., De, J.I., Pepe, L., Mannazzu, I., Ciani, M. (2004a). Pichia anomala and Kluyveromyces wickerhamii killer toxins as new tools against Dekkera/Brettanomyces spoilage yeasts. FEMS Microbiology Letters, 238(1), 235-240.

https://doi.org/10.1111/j.1574-6968.2004.tb09761.x

9. Comitini, F., Di Pietro, N., Zacchi, L., Mannazzu, I., Ciani, M. (2004b). Kluyveromyces phaffii killer toxin active against wine spoilage yeasts: purification and characterization. Microbiology, 150(8), 2535-2541.

https://doi.org/10.1099/mic.0.27145-0

10. Cordero-Bueso, G., Mangieri, N., Maghradze, D., Foschino, R., Valdetara, F., Cantoral, J.M., Vigentini, I. (2017). Wild grape-associated yeasts as promising biocontrol agents against Vitis vinifera fungal pathogens. Frontiers in Microbiology, 8, art. no. 2025. https://doi.org/10.3389/fmicb.2017.02025

11. Crafack, M., Mikkelsen, M.B., Saerens, S., Knudsen, M., Blennow, A., Lowor, S., Takrama, J., Swiegers, J.H., Petersen, G.B., Heimdal, H. (2013). Influencing cocoa flavour using Pichia kluyveri and Kluyveromyces marxianus in a defined mixed starter culture for cocoa fermentation. International Journal of Food Microbiology, 167(1), 103-116.

https://doi.org/10.1016/j.ijfoodmicro.2013.06.024

12. Droby, S. (2005). Improving quality and safety of fresh fruits and vegetables after harvest by the use of biocontrol agents and natural materials. Acta Horticulturae, 709, 45-52.

https://doi.org/10.17660/ActaHortic.2006.709.5

13. Du Toit, M., Pretorius, I.S. (2000). Microbial spoilage and preservation of wine: using weapons from nature's own arsenal a review. South African Journal of Enology and Viticulture, 21(1), 74-96. https://doi.org/10.21548/21-1-3559

14. El-Ghaouth, A., Wilson, C., Wisniewski, M. (2004). Biologicallybased alternatives to synthetic fungicides for the control of postharvest diseases of fruit and vegetables. In: Naqvi, S.A.M.H. (Eds.), Diseases of Fruits and Vegetables. Volume II. Springer, Dordrecht, pp. 511-535. https://doi.org/10.1007/1-4020-2607-2_14

15. Fiori, S., Urgeghe, P.P., Hammami, W., Razzu, S., Jaoua, S., Migheli, Q. (2014). Biocontrol activity of four non-and low- -fermenting yeast strains against Aspergillus carbonarius and their ability to remove ochratoxin A from grape juice. International Journal of Food Microbiology, 189, 45-50.

https://doi.org/10.1016/j.ijfoodmicro.2014.07.020

16. Fourie, P.H., Holz, G., Calitz, F.J. (2002). Occurrence of Botrytis cinerea and Monilinia laxa on nectarine and plum in Western Cape orchards, South Africa. Australasian Plant Pathology, 31, 197-204.

https://doi.org/10.1071/AP02007

17. Fredlund, E., Blank, L.M., Schnürer, J., Sauer, U., Passoth, V. (2004). Oxygen-and glucose-dependent regulation of central carbon metabolism in Pichia anomala. Journal of Applied Environmental Microbiology, 70(10), 5905-5911.

https://doi.org/10.1128/AEM.70.10.5905-5911.2004

18. Gril, T., Celar, F., Munda, A., Javornik, B., Jakse, J. (2008). AFLP analysis of intraspecific variation between Monilinia laxa isolates from different hosts. Plant Disease, 92(12), 1616-1624.

https://doi.org/10.1094/PDIS-92-12-1616

19. Grzegorczyk, M., Żarowska, B., Restuccia, C., Cirvilleri, G. (2017). Post-harvest biocontrol ability of killer yeasts against Monilinia fructigena and Monilinia fructicola on stone fruit. Food Microbiology, 61, 93-101.

https://doi.org/10.1016/j.fm.2016.09.005

20. Hernández, A., Martín, A., Córdoba, M.G., Benito, M.J., Aranda, E., Pérez-Nevado, F. (2008). Determination of killer activity in yeasts isolated from the elaboration of seasoned green table olives. International Journal of Food Microbiology, 121 (2), 178-188. https://doi.org/10.1016/j.ijfoodmicro.2007.11.044

21. Huang, R., Che, H.J., Zhang, J., Yang, L., Jiang, D.H., Li, G.Q. (2012). Evaluation of Sporidiobolus pararoseus strain YCXT3 as biocontrol agent of Botrytis cinerea on post-harvest strawberry fruits. Biological Control, 62(1), 53-63.

https://doi.org/10.1016/j.biocontrol.2012.02.010

22. Huang, R., Li, G.Q., Zhang, J., Yang, L., Che, H.J., Jiang, D.H., Huang, H.C. (2011). Control of post-harvest Botrytis fruit rot of strawberry by volatile organic compounds of Candida intermedia. Phytopathology, 101 (7), 859-869.

https://doi.org/10.1094/PHYTO-09-10-0255

23. Jolly, N.P., Varela, C., Pretorius, I.S. (2014). Not your ordinary yeast: non-Saccharomyces yeasts in wine production uncovered. FEMS Yeast Research, 14(2), 215-237. https://doi.org/10.1111/1567-1364.12111

24. Liu, J., Sui, Y., Wisniewski, M., Droby, S., Liu, Y. (2013). Review: utilization of antagonistic yeasts to manage post-harvest fungal diseases of fruit. International Journal of Food Microbiology, 167(2), 153-160.

https://doi.org/10.1016/j.ijfoodmicro.2013.09.004

25. Lutz, M.C., Lopes, C.A., Rodriguez, M.E., Sosa, M.C., Sangorrín, M.P. (2013). Efficacy and putative mode of action of native and commercial antagonistic yeasts against post-harvest pathogens of pear. International Journal of Food Microbiology, 164(2-3), 166-172.

https://doi.org/10.1016/j.ijfoodmicro.2013.04.005

26. Medina-Córdova, N., López-Aguilar, R., Ascencio, F., Castellanos, T., Campa-Córdova, A.I., Angulo, C. (2016). Biocontrol activity of the marine yeast Debaryomyces hansenii against phytopathogenic fungi and its ability to inhibit mycotoxins production in maize grain (Zea mays L.). Biological Control, 97, 70-79. https://doi.org/10.1016/j.biocontrol.2016.03.006 
27. Mehlomakulu, N.N., Setati, M.E., Divol, B. (2014). Characterization of novel killer toxins secreted by wine-related non-Saccharomyces yeasts and their action on Brettanomyces spp. International Journal of Food Microbiology, 188, 83-91. https://doi.org/10.1016/j.ijfoodmicro.2014.07.015

28. Mewa-Ngongang, M., du Plessis, H.W., Hutchinson, U.F., Mekuto, L., Ntwampe, S.K. (2017). Kinetic modelling and optimisation of antimicrobial compound production by Candida pyralidae KU736785 for control of Candida guilliermondii. Food Science and Technology International, 23(4), 358-370. https://doi.org/10.1177/1082013217694288

29. Mewa-Ngongang, M., du Plessis, H.W., Ntwampe, S.K., Chidi, B.S., Hutchinson, U.F., Mekuto, L., Jolly, N.P. (2019a). Grape pomace extracts as fermentation medium for the production of potential biopreservation compounds. Foods, 8(2), art. no. 51. https://doi.org/10.3390/foods8020051

30. Mewa-Ngongang, M., du Plessis, H.W., Ntwampe, S.K.O., Chidi, B.S., Hutchinson, U.F., Mekuto, L., Jolly, N.P. (2019b). The use of Candida pyralidae and Pichia kluyveri to control spoilage microorganisms of raw fruits used for beverage production. Foods 8(10), art. no. 454. https://doi.org/10.3390/foods8100454

31. Morales, H., Marín, S., Rovira, A., Ramos, A.J., Sanchis, V. (2007). Patulin accumulation in apples by Penicillium expansum during postharvest stages. Letters in Applied Microbiology, 44(1), 30-35. https://doi.org/10.1111/j.1472-765X.2006.02035.x

32. Muccilli, S., Restuccia, C. (2015). Bioprotective role of yeasts. Microorganisms, 3(4), 588-611. https://doi.org/10.3390/microorganisms3040588

33. Nally, M.C., Pesce, V.M., Maturano, Y.P., Rodriguez-Assaf, L.A., Toro, M.E., Castellanos de Figueroa, L.I., Vazquez, F. (2015). Antifungal modes of action of Saccharomyces and other biocontrol yeasts against fungi isolated from sour and grey rots. International Journal of Food Microbiology, 204, 91-100. https://doi.org/10.1016/j.ijfoodmicro.2015.03.024

34. Núñez, F., Lara, M.S., Peromingo, B., Delgado, J., Sánchez-Montero, L., Andrade, M.J. (2015). Selection and evaluation of Debaryomyces hansenii isolates as potential bioprotective agents against toxigenic penicillia in dry-fermented sausages. Food Microbiology, 46, 114-120. https://doi.org/10.1016/j.fm.2014.07.019

35. Oro, L., Ciani, M., Comitini, F. (2014). Antimicrobial activity of Metschnikowia pulcherrima on wine yeasts. Journal of Applied Microbiology, 116(5), 1209-1217. https://doi.org/10.1111/jam.12446

36. Parveen, S., Wani, A.H., Bhat, M.Y., Koka, J.A., Wani, F.A. (2016). Management of post-harvest fungal rot of peach (Prunus persica) caused by Rhizopus stolonifer in Kashmir Valley, India. Plant Pathology \& Quarantine, 6(1), 19-29.

https://doi.org/10.5943/ppq/6/1/4

37. Psani, M., Kotzekidou, P. (2006). Technological characteristics of yeast strains and their potential as starter adjuncts in Greek-style black olive fermentation. World Journal of Microbiology and Biotechnology, 22, 1329-1336.

https://doi.org/10.1007/s11274-006-9180-y

38. Sáez, J.S., Lopes, C.A., Kirs, V.C., Sangorrín, M.P. (2010). Enhanced volatile phenols in wine fermented with Saccharomyces cerevisiae and spoiled with Pichia guilliermondii and Dekkera bruxellensis. Letters in Applied Microbiology, 51 (2), 170-176. https://doi.org/10.1111/j.1472-765X.2010.02878.x

39. Sansone, G.Y., Lambrese, V., Calvente, G., Fernández, D., Benuzzi, M., Sanz Ferramola, M. (2018). Evaluation of Rhodosporidium fluviale as biocontrol agent against Botrytis cinerea on apple fruit. Letters in Applied Microbiology, 66(5), 455-461.

https://doi.org/10.1111/lam.12872

40. Sharma, R.R., Singh, D., Singh, R. (2009). Biological control of post-harvest diseases of fruits and vegetables by microbial antagonists: A review. Biological Control, 50(3), 205-221. https://doi.org/10.1016/j.biocontrol.2009.05.001

41. Singh, D., Sharma, R.R. (2007). Post-Harvest Diseases Of Fruit, Vegetables, And Their Management, first ed. Daya Publishing House, New Delhi, India.

42. Thompson, R.S., Aveling, T.A.S., Blanco, P.R. (2013). A new semi-selective medium for Fusarium graminearum, F. proliferatum, F. subglutinans and F. verticillioides in maize seed. South African Journal of Botany, 84, 94-101. https://doi.org/10.1016/j.sajb.2012.10.003

43. Tipper, D.J., Bostian, K.A. (1984). Double-stranded ribonucleic acid killer systems in yeasts. Microbiological Reviews, 48(2), $125-156$. https://doi.org/10.1128/mr.48.2.125-156.1984

44. Williamson, B., Tudzynski, B., Tudzynski, P., Van Kan, J.A. (2007). Botrytis cinerea: the cause of grey mould disease. Molecular Plant Pathology, 8(5), 561-580. https://doi.org/10.1111/j.1364-3703.2007.00417.x

45. Zhu, C., Shi, J., Jiang, C., Liu, Y. (2015). Inhibition of the growth and ochratoxin A production by Aspergillus carbonarius and Aspergillus ochraceus in vitro and in vivo through antagonistic yeasts. Food Control, 50, 125-132. https://doi.org/10.1016/j.foodcont.2014.08.042

46. Zhu, S.J. (2006). Non-chemical approaches to decay control in post-harvest fruit. In Advances in Postharvest Technologies for Horticultural Crops. Research Signpost, Trivandrum, India, ISBN, 8130801108, pp. 297-313. 